\title{
ANALISIS ESTIMASI BIAYA PROYEK PEMBANGUNAN KARGO BANDARA INTERNASIONAL JAWA BARAT (BIJB) KERTAJATI DENGAN METODE COST SIGNIFICANT MODEL
}

\author{
Rony Qurniawan ${ }^{1}$, Agus Rachmat ${ }^{2}$, Yushar Kadir ${ }^{3}$ \\ Pascasarjana Universitas Sangga Buana YPKP, Bandung \\ ${ }^{1}$ korespondensi: qurniaoneronny @gmail.com
}

\begin{abstract}
The writer has done the research about the cost project estimation of airport cargo building project by using Cost Significat Model method. The formulation of problems which the writer wants to find out are: (1) what is the job component item that influence significantly toward the total of airport cargo building cost?, (2) how is the cost estimation model of the airport cargo building project by using the Cost Significat Model method?, and (3) how is the cost estimation model accuration comparation of the airport cargo building cost by using Cost Significat Model method?. This research uses quantitative approach by taking the cost data in the form of the cost budget plan (RAB) of three provinces airport cargo building including, West Java Province (in Majalengka), Central Java Province (in Kulon Progo), and North Sumatra Province (in Medan). The result of this research analysis are (1) the component item jobs which influenced significantly toward the total of the airport cargo building cost based on the calculation by using cost significat model method are (a) $\mathrm{X}_{2}$ Structure Job; 63,93\%, (b) $X_{3}$ Architecture Job: 27,75\%, and (c) $X_{6}$ Electrical Job: 5,69\%; (2) Cost Estimation airport cargo building by using Cost Significant Model method in 3 provinces is $\boldsymbol{Y}=208,453+0,747 \boldsymbol{X}_{2}+1,505 \boldsymbol{X}_{3}$ $+1,844 X_{6}$; (3) The average result of the comparation accuration of airport cargo building project cost estimation model in three provinces by using Cost Significant Model method is 47,65\%, and as the AACE international standard that the cost estimation result including class 2 with Usage: Control or Bid/Tender which is appropriate with 2.2 tabel in page 28.
\end{abstract}

Keywords: airport cargo, cost significant item

\begin{abstract}
ABSTRAK
Penulis melaksanakan penelitian yang berkaitan dengan estimasi biaya proyek dengan menggunakan metode Cost Significant Model pada proyek pembangunan gedung kargo bandara. Hal ini didasarkan rumusan masalah yang penulis ajukan, yakni (1) komponen item pekerjaan apakah yang berpengaruh secara signifikan terhadap biaya total pembangunan kargo bandara?, (2) bagaimana model estimasi biaya pembangunan kargo bandara dengan menggunakan metode Cost Significant Model?, dan (3) bagaimana perbandingan akurasi model estimasi biaya pembangunan kargo bandara dengan menggunakan metode Cost Significant Model?. Penelitian ini menggunakan pendekatan kuantitatif dengan mengambil data biaya berupa rencana anggaran biaya (RAB) pembangunan kargo bandara di 3 provinsi, yakni Provinsi Jawa Barat (di Majalengka), Provinsi Jawa Tengah (di Kulon Progo), dan Provinsi Sumatra Utara (di Medan). Hasil analisis penelitian ini adalah (1) komponen item pekerjaan yang berpengaruh secara signifikan terhadap biaya total pembangunan kargo bandara berdasarkan perhitungan dengan metode cost significant model adalah (a) $X_{2}$ Pekerjaan Struktur: 63,93\%, (b) $X_{3}$ Pekerjaan Arsitektur: 27,75\%, dan (c) $X_{6}$ Pekerjaan Elektrikal: 5,69\%; (2) Model estimasi biaya pembangunan kargo bandara dengan menggunakan metode Cost Significant Model di 3 provinsi adalah $\boldsymbol{Y}=208,453+0,747 \boldsymbol{X}_{\mathbf{2}}+1,505 \boldsymbol{X}_{\mathbf{3}}+1,844 \boldsymbol{X}_{\mathbf{6}} ;$ (3) Perbandingan akurasi model estimasi biaya pembangunan kargo bandara di 3 provinsi dengan menggunakan metode Cost Significant Model diperoleh rata-rata 47,65\%, serta menurut Standar AACE International bahwa hasil estimasi biaya ini termasuk ke dalam class 2 dengan Usage: Control or Bid/Tender sesuai tabel 2.2 pada halaman 28.
\end{abstract}

Kata Kunci: kargo bandara, cost significant item

PENDAHULUAN

\section{Latar Belakang}

Pemerintah Provinsi Jawa Barat sejak tahun

2002 telah merencanakan pembangunan
Bandara Internasional Jawa Barat (BIJB). Pembangunan bandar udara ini dimaksudkan untuk pemenuhan pelayanan transportasi udara bagi masyarakat yang semakin 
meningkat. Kemudian, pendapat lainnya mengungkapkan bahwa bahwa dibangunnya Bandara Internasional Jawa Barat ini diharapkan dapat menciptakan kondisi [1] seperti berikut ini.

1) Terjadinya percepatan pertumbuhan investasi yang akan berdampak pada pertumbuhan ekonomi di Jawa Barat.

2) Meningkatkan Indeks Pembangunan Manusia (IPM) Jawa Barat.

3) Peningkatan pariwisata Jawa Barat dan pelayanan jemaah haji asal Jawa Barat dan sekitarnya.

Bandara Internasional Jawa Barat (BIJB) Kertajati Majalengka merupakan pengembangan hubungan baru di Pulau Jawa yang berada di kawasan lokasi proyek di Kecamatan Kertajati Provinsi Jawa Barat sesuai studi kelayakan tahun 2003. Kebersihan lahan seluas 1.800 hektar, saat ini yang telah dibebaskan seluas 1.000 hektar. Area ini nantinya akan cukup untuk menampung landasan pacu yang dapat menampung pesawat berbadan lebar, terminal internasional, domestik, dan kargo serta fasilitas pendukung, dan perluasan lebih lanjut dari fasilitas bandara [2].

Fungsi dari bandara adalah sebagai suatu tempat dengan segala perlengkapan beserta gedungnya, kemudian sebagai tempat untuk pemberangkatan, pendaratan, dan pelayanan bagi pesawat terbang dengan segala muatannya, berupa penumpang dan barang. Sekaitan dengan muatan berupa barang bahwasanya bandara harus memiliki terminal barang (kargo). Terminal barang [3] merupakan salah satu pokok pelayanan di bandar udara untuk memproses pengiriman dan penerimaan muatan udara (domestik maupun internasional) yang bertujuan untuk kelancaran proses kargo serta memenuhi persyaratan keamanan dan keselamatan penerbangan. Dengan demikian, setiap perencanaan untuk terminal kargo harus diperhitungkan terlebih dahulu.

Adapun penelitian ini didasarkan pada studi pendahuluan yang penulis laksanakan melalui observasi, wawancara, dan studi pustaka. Tujuan studi pendahuluan untuk mengetahui masalah penelitian yang akan penulis analisis. Sekaitan dengan judul penelitian yang penulis ajukan bahwasanya latar belakang masalah penelitian ini adalah sebagai berikut.

1) Pengembangan hubungan baru di Pulau Jawa yang berada di kawasan lokasi proyek di Kecamatan Kertajati, Kabupaten Majalengka, Propinsi Jawa Barat sesuai dengan Studi Kelayakan Tahun 2003.

2) Kargo yang sesuai dengan kelas bandara internasional dan pertama di Propinsi Jawa Barat.

3) Pemilihan estimasi biaya dalam penelitian ini karena adanya kaitan/hubungan dengan program studi pascasarjana yang sedang penulis tempuh yakni manajemen konstruksi.

Berdasarkan penjelasan mengenai estimasi biaya bahwasanya penulis akan melakukan penelitian analisis estimasi biaya pada bangunan kargo di bandara. Oleh karena itu, penulis memilih teknik pembuatan model 
estimasi biaya awal yang lebih representatif, efektif, dan akurat, yakni berupa metode Cost Significant Model. Metode ini dapat dikembangkan di Indonesia karena proses tender di Indonesia kadangkala dipengaruhi oleh budaya setempat [4]. Hubungan berdasarkan kepercayaan antara owner dan kontraktor dapat mengurangi perhitungan estimasi proyek secara detail. Kontraktor cukup hanya mengidentifikasi dan menggambarkan secara kebutuhan proyek dan menegoisasi harga.

\section{Rumusan Masalah Penelitian}

Pada penelitian ini terdapat rumusan masalah yang berdasarkan pada penjelasan latar belakang yang telah diuraikan di atas, yakni sebagai berikut.

1) Dalam biaya total pembangunan Kargo Bandara Internasional Jawa Barat (BIJB) Kertajati Majalengka, komponen item pekerjaan apa yang memiliki pengaruh secara signifikan?

2) Bagaimana model estimasi biaya pembangunan Kargo Bandara Internasional Jawa Barat (BIJB) Kertajati Majalengka dengan menggunakan metode cost significant model?

3) Bagaimana perbandingan akurasi model estimasi biaya pembangunan Kargo Bandara Internasional Jawa Barat (BIJB) Kertajati Majalengka dengan menggunakan metode cost significant model?

\section{Maksud dan Tujuan Penelitian}

Adapun maksud dari penelitian ini adalah untuk menjelaskan informasi penggunaan metode cost significant model pada biaya awal proyej pembangunan kargo bandara dengan tepat, hasil akurat, dan mudah dipergunakan oleh (1) pemilik proyek dalam mengetahui prediksi awal besarnya biaya yang akan dikeluarkan dalam pembangunan kargo bandara, (2) konsultan perencana sebagai panduan studi kelayakan dan desain awal dalam pembangunan kargo bandara, dan (3) kontraktor sebagai orang pertama yang mengestimasikan dalam menilai bangunan kargo yang akan dikerjakan.

Kemudian, tujuan penelitian ini adalah untuk mendeskripsikan (1) biaya total pembangunan Kargo Bandara Internasional Jawa Barat (BIJB) Kertajati Majalengka dengan mengidentifikasi komponen item pekerjaan apa yang memiliki pengaruh signifikan, (2) suatu model estimasi biaya pembangunan Kargo Bandara Internasional Jawa Barat (BIJB) Kertajati Majalengka dengan menggunakan metode cost significant model, dan (3) perbandingan akurasi model estimasi biaya pembangunan Kargo Bandara Internasional Jawa Barat (BIJB) Kertajati Majalengka dengan menggunakan metode cost significant model.

\section{Manfaat Penelitian}

Adapun manfaat dari penelitian ini adalah sebagai berikut.

1) Manfaat Teoretis

Hasil penelitian ini diharapkan dapat memperluas khazanah ilmu pengetahuan, 
terutama di bidang teknik sipil, serta menambah wawasan dan pengetahuan tentang manajemen konstruksi khususnya estimasi biaya suatu proyek.

2) Manfaat Praktis

a. Bagi Penulis

Secara langsung penulis dapat memahami model estimasi yang menggambarkan rencana biaya pada tahap awal proyek pembangunan Kargo Bandara Internasional Jawa Barat (BIJB) Kertajati Majalengka dengan tepat, cepat, dan dapat dipertanggungjawabkan.

b. Bagi Dunia Jasa Konstruksi

Dalam bidang jasa konstruksi, penelitian ini diharapkan memberikan gambaran tentang estimasi biaya total proyek pembangunan Kargo Bandara
Internasional Jawa Barat (BIJB) Kertajati Majalengka dengan tepat, cepat, dan dapat dipertanggungjawabkan.

\section{TINJAUAN PUSTAKA}

Estimasi Biaya Proyek

Estimasi merupakan rangkaian kegiatan konstruksi yang berkaitan dengan besaran dana yang dibutuhkan dalam mewujudkan suatu proyek [5]. Perkiraan biaya adalah seni memperkirakan biaya atau the art of approximating merupakan suatu cara memperkirakan jumlah biaya yang diperlukan dalam suatu kegiatan yang berdasarkan pada informasi yang tersedia [5]. Biasanya berkaitan erat dengan analisis biaya, maksudnya analisis biaya pada kegiatan terdahulu akan digunakan sebagai referensi untuk menyusun rencana anggaran.

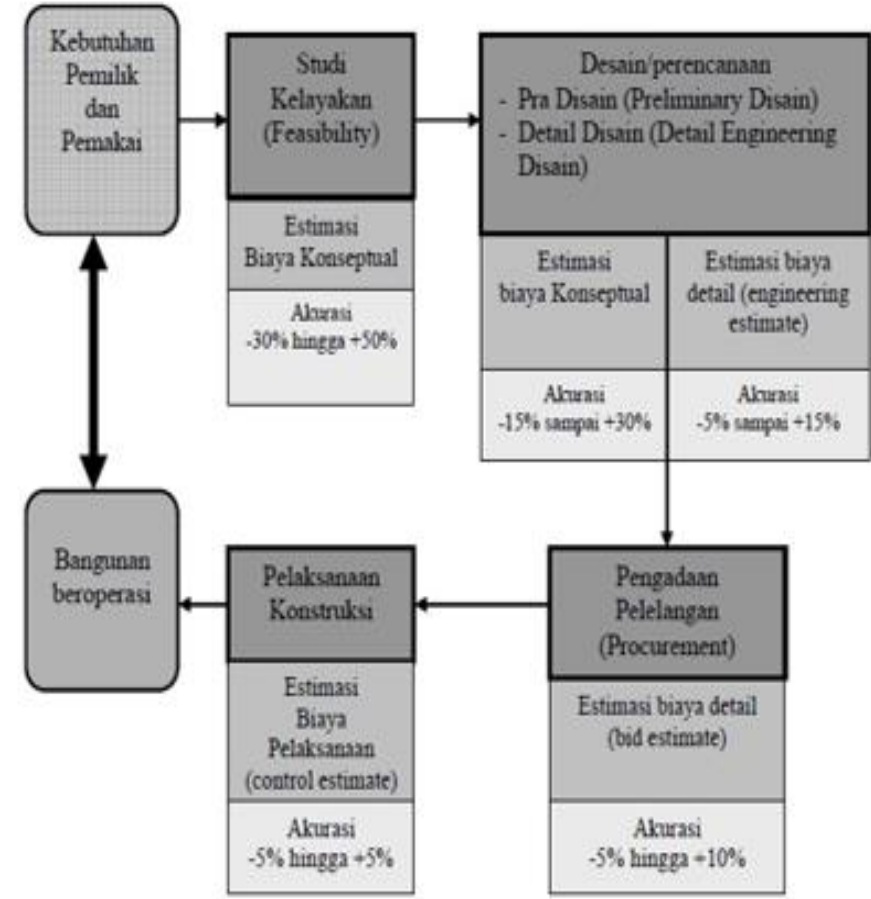

Gambar 1 : Gambar Tahapan Proyek Konstruksi 
1) Pada tahun pelaksanaan disesuaikan dengan harga pada tahun yang diproyeksikan dengan memperhitungkan faktor inflasi. Pengaruh time value dapat dihitung karena berkurangnya nilai uang akibat faktor inflasi tiap tahunnya. Perhitungan menggunakan future value (FV) [5] dengan persamaan (1)

$$
F=P(\mathbf{1}+\mathbf{f})^{n}
$$

Keterangan

Harga pada tahun pelaksanaan (present)

$$
=\mathrm{P}
$$

Nilai harga pada tahun yang ditentukan (future) $\quad=\mathrm{F}$

Faktor inflasi $=\mathrm{f}$

Tahun $\quad=\mathrm{n}$

2) Mencari cost significant items yang diidentifikasikan sebagai item-item terbesar yang jumlahnya kumulatif persentasenya sama atau lebih besar dari $80 \%$ total biaya proyek.

3) Membuat model biaya dari cost significant items yang telah ditentukan.

4) Mencari rata-rata cost model factor (CMF). CMF didapatkan dengan cara membagi nilai proyek yang didapatkan dari model dengan nilai aktual proyek.

5) Menghitung estimasi biaya dari cost significant model dengan cara membagi nilai proyek yang diprediksi dari model dengan rata-rata $\mathrm{CMF}$.

6) Menghitung akurasi model dalam bentuk prosentase dari selisih antara harga yang diprediksi dengan harga sebenarnya dibagi dengan harga sebenarnya.

$$
\text { Akurasi }=\frac{(E v-A v)}{A v} \times 100 \%
$$

Keterangan:

$\mathrm{Ev}=$ Harga yang diprediksi/Estimated bill value

$\mathrm{Av}=$ Harga yang sebenarnya/Actual bill value

Metode cost significant model memiliki beberapa kelebihan, yakni memperhitungkan biaya total proyek secara akurat, cepat, dan mudah, serta (2) dalam penyusunan perencanaan pendahuluan, studi kelayakan, maupun konsep, metode ini dapat digunakan. Kemudian, kekurangan dari metode cost significant model adalah (1) adanya penggunaan data historis proyek yang lalu, (2) peninjauan terhadap proyek harus sama, dan (3) baik tidaknya data yang terkumpulkan sangat mempengaruhi akurasi model. Kemudian, penulis melaksanakan penelitian ini adalah untuk menganalisis item pekerjaan yang termasuk ke dalam Cost Significant pada rencana anggaran biaya lalu melaksanakan proses perhitungan melalui persamaan regresi berganda. Selanjutnya, mengklasifikasi tingkat keakuratan estimasi berdasarkan tahap dalam proyek serta model biaya yang dapat digunakan berdasarkan American Association of Cost Engineer (AACE) International (2005). Berikut gambar AACE International. 
ISSN 1979-4835

E-ISSN 2721-2335

\begin{tabular}{|c|c|c|c|c|c|}
\hline \multirow[b]{2}{*}{$\begin{array}{l}\text { ESTIMATE } \\
\text { CLASS }\end{array}$} & \multirow{2}{*}{$\begin{array}{c}\begin{array}{c}\text { Primary } \\
\text { Characteriatic }\end{array} \\
\text { LEVEL of } \\
\text { PROJECT } \\
\text { DEFINITION } \\
\text { Expessed as } \% \text { of } \\
\text { complete defintion }\end{array}$} & \multicolumn{4}{|c|}{ Seecondary Cheracteriatle } \\
\hline & & $\begin{array}{l}\text { END USAGE } \\
\text { Typical purpose of } \\
\text { estimate }\end{array}$ & $\begin{array}{l}\text { METH ODOLOOY } \\
\text { Typical estimating } \\
\text { mathod }\end{array}$ & $\begin{array}{l}\text { EXPECTED } \\
\text { ACCURACY } \\
\text { RANGE } \\
\text { Typlcal variation in } \\
\text { low and high } \\
\text { anges }[\mathrm{e}]\end{array}$ & $\begin{array}{l}\text { PREPARATION } \\
\text { EFFORT } \\
\text { Typical degree of } \\
\text { effot relative io } \\
\text { inast cost index of } \\
\text { I [D] }\end{array}$ \\
\hline Cless 5 & $0 x$ to $2 \%$ & Concept Soreening & $\begin{array}{l}\text { Capacily Faclored, } \\
\text { Parameitic Models, } \\
\text { Judoment, of } \\
\text { Analogy }\end{array}$ & $\begin{array}{l}\text { L: }-20 \% \text { क } 50 \% \\
\mathrm{H}:+30 \% \text { to }+100 \%\end{array}$ & 1 \\
\hline Class 4 & $1 \%$ to $15 \%$ & Study of Feas biry & $\begin{array}{c}\text { Equpment } \\
\text { Faesored } \alpha \\
\text { Parametic Modab }\end{array}$ & $\begin{array}{l}\text { L. }-15 \% \text { bo }-30 \% \\
\text { H: }+20 \% \text { io }+50 \%\end{array}$ & 2 to 4 \\
\hline Class 3 & $10 \%$ to $40 \%$ & $\begin{array}{l}\text { Budget, } \\
\text { Authorization, of } \\
\text { Control }\end{array}$ & $\begin{array}{l}\text { Semp-Detaled Uni } \\
\text { Costs with } \\
\text { Aesembly Level } \\
\text { Uine Hems }\end{array}$ & $\begin{array}{l}\text { L: }-10 \% \text { to }-20 \% \\
\mathrm{H}:+10 \% \text { to }+30 \%\end{array}$ & 31010 \\
\hline Class 2 & $30 \%$ to $70 \%$ & $\begin{array}{c}\text { Control or Bdf } f \\
\text { Tender }\end{array}$ & $\begin{array}{l}\text { Detaled Unit Cos: } \\
\text { with Forced } \\
\text { Detailed Take-OIt }\end{array}$ & $\begin{array}{l}\text { L. } 5 \% \text { bo }=15 \% \\
H,+5 \% \times 0+20 \%\end{array}$ & 4020 \\
\hline Class 1 & Ses to $100 \%$ & $\begin{array}{c}\text { Check Esimath of } \\
\text { BidTender }\end{array}$ & $\begin{array}{c}\text { Detaled Unit Cos: } \\
\text { with Detaled Take- } \\
\text { Of }\end{array}$ & $\begin{array}{l}\text { L: }-3 \% \text { tb-10\% } \\
\text { H: }+3 \% \text { to }+15 \%\end{array}$ & 510100 \\
\hline
\end{tabular}

Noles [a] The stale of process iechnology and availablity of appleable reference cost data aflect the range markecty. The 4/-valuo represtents typica percentage vaitason of actual costs from the coet estinate ater applea tion of contingency (typicaly at a $50 \%$ level of confidence) for given secps.

(b) If the arce index wive of "Y" represents $0.005 \%$ of propect eosts, then an index value of t00 represents $0.5 \%$. Estimain preparatibn effort is hichly dependent upon the size of the project and the qualiy of estimating data and tools.

Gambar 2: Gambar Klasifikasi Estimasi Biaya Menurut AACE International

\section{METODE PENELITIAN}

Penelitian ini menggunakan pendekatan kuantitatif. Dalam hal ini penulis melaksanakan studi pendahuluan melalui observasi, studi pustaka, dan studi analisis. Penulis pun mengujicobakan metode cost significant model pada estimasi biaya proyek, efektif atau tidak?. Tentu dengan mengujicobakan tersebut harus menggunakan perhitungan secara statistik. Berikut gambar alur penelitian. 


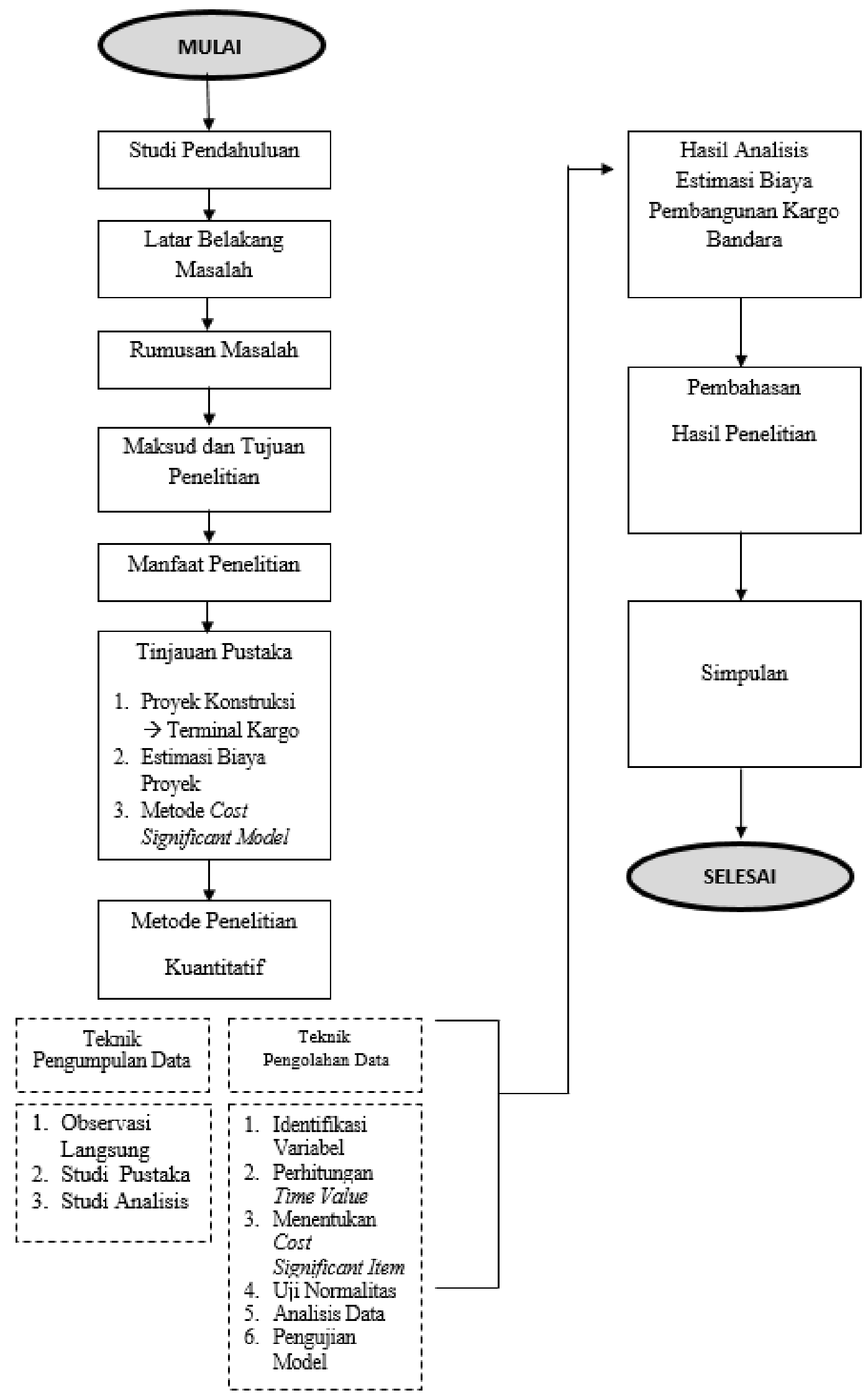

Gambar 3 : Alur Penelitian 


\section{HASIL DAN PEMBAHASAN}

Data dalam penelitian ini didapat dari data histori penawaran proyek pemenang tender pembangunan kargo bandara di 3 provinsi, yakni Provinsi Jawa Barat (di Majalengka), Provinsi Jawa Tengah (di Kulon Progo), dan
Provinsi Sumatra Utara (di Medan). Adapun data yang dikumpulkan sebanyak 3 proyek, serta harga yang dimaksud dalam pembangunan kargo bandara di 3 provinsi tersebut adalah belum termasuk PPN (Pajak Pertambahan Nilai) sebesar $10 \%$

Tabel 1 : Data Proyek Pembangunan Gedung Kargo Bandara di Provinsi Sumatra Utara (di Medan/Tahun 2013), Provinsi Jawa Barat (di Majalengka/Tahun 2017), dan Provinsi Jawa Tengah (di Kulon Progo/Tahun 2018)

\begin{tabular}{|c|c|c|c|c|c|c|c|c|c|}
\hline No & $\begin{array}{c}\text { Nama } \\
\text { Proyek }\end{array}$ & Tahun & $\begin{array}{c}\text { Jumlah Biaya } \\
(\mathbf{Y})^{*}\end{array}$ & $\begin{array}{c}\text { Pek } \\
\text { Persiapan } \\
\left(\mathbf{X}_{\mathbf{1}}\right)^{*}\end{array}$ & $\begin{array}{c}\text { Pek Struktur } \\
\left(\mathbf{X}_{\mathbf{2}}\right)^{*}\end{array}$ & $\begin{array}{c}\text { Pek } \\
\text { Arsitektur } \\
\left(\mathbf{X}_{\mathbf{3}}\right)^{*}\end{array}$ & $\begin{array}{c}\text { Pek } \\
\text { Plumbing } \\
\left(\mathbf{X}_{\mathbf{4}}\right)^{*}\end{array}$ & $\begin{array}{c}\text { Pek } \\
\text { Mekanikal } \\
\left(\mathbf{X}_{\mathbf{5}}\right)^{*}\end{array}$ & $\begin{array}{c}\text { Pek } \\
\text { Elektrikal } \\
\left(\mathbf{X}_{\mathbf{6}}\right)^{*}\end{array}$ \\
\hline$(1)$ & $(2)$ & $(3)$ & $(4)=(5+6+7+8+9+10)$ & $(5)$ & $(6)$ & $(8)$ & $(9)$ & $(10)$ \\
\hline 1 & $\begin{array}{c}\text { Kargo } \\
\text { Bandara } \\
\text { Kualanamu }\end{array}$ & 2013 & $18,526,282,106$ & $115,646,151$ & $11,918,152,485$ & $5,472,121,650$ & $54,286,528$ & $212,999,546$ & $753,075,746$ \\
2 & $\begin{array}{c}\text { Kargo } \\
\text { Bandara } \\
\text { BIJB }\end{array}$ & 2017 & $29,621,728,214$ & $208,914,231$ & $17,252,477,903$ & $8,460,743,910$ & $211,932,527$ & $1,317,802,542$ & $2,169,857,102$ \\
\hline 3 & $\begin{array}{c}\text { Kargo } \\
\text { Bandara } \\
\text { NYIA }\end{array}$ & 2018 & $56,261,042,866$ & $258,950,897$ & $40,358,305,228$ & $9,745,774,718$ & $204,434,191$ & $713,556,045$ & $4,980,021,787$ \\
\hline \hline
\end{tabular}

Keterangan : $(*)=$ Dalam Miliaran Rupiah

Sebelum data di input ke dalam program SPSS Ver 25 , maka data sekunder yang telah di dapat dari histori penawaran perlu diolah. Luas bangunan masing-masing proyek gedung kargo bandara berbeda-beda, sehingga perlu untuk diseragamkan datanya. Data yang akan disesuaikan menjadi biaya per $\mathrm{m}^{2}$ luas bangunan. Biaya total pekerjaan (Y) dan komponen biaya ( $\mathrm{X}_{1}$ sampai dengan $\left.\mathrm{X}_{6}\right)$ dibagi luasan bangunan untuk masing-masing proyek gedung kargo bandara, sehingga $\mathrm{Y}$ adalah biaya per $\mathrm{M}^{2}$ luas bangunan dan komponen biaya ( $\mathrm{X}_{1}$ sampai dengan $\left.\mathrm{X}_{6}\right)$ adalah komponen biaya per $\mathrm{M}^{2}$ luas bangunan. 
Tabel 2 : Tabulasi Data Proyek Pembangunan Gedung Kargo di Provinsi Sumatra Utara (di Medan/Tahun 2013), Provinsi Jawa Barat (di Majalengka/Tahun 2017), dan Provinsi Jawa Tengah (di Kulon Progo/Tahun 2018), per $\mathbf{m}^{2}$

\begin{tabular}{|c|c|c|c|c|c|c|c|c|c|c|}
\hline No & $\begin{array}{l}\text { Nama } \\
\text { Proyek }\end{array}$ & Tahun & $\begin{array}{c}\text { Jumlah Biaya } \\
(\mathbf{Y})^{*}\end{array}$ & $\begin{array}{c}\text { Pek } \\
\text { Persia } \\
\text { pan } \\
\left(\mathrm{X}_{1}\right)^{*}\end{array}$ & $\begin{array}{c}\text { Pek } \\
\text { Struktur } \\
\left(\mathbf{X}_{2}\right)^{*}\end{array}$ & $\begin{array}{c}\text { Pek } \\
\text { Arsitektur } \\
\left(\mathbf{X}_{3}\right)^{*}\end{array}$ & $\begin{array}{c}\text { Pek } \\
\text { Plumbing } \\
\left(\mathrm{X}_{4}\right)^{*}\end{array}$ & $\begin{array}{c}\text { Pek } \\
\text { Mekanikal } \\
\left(\mathrm{X}_{5}\right)^{*}\end{array}$ & $\begin{array}{c}\text { Pek } \\
\text { Elektrikal } \\
\left(\mathbf{X}_{\mathbf{6}}\right)^{*}\end{array}$ & $\begin{array}{c}\text { Ketera } \\
\text { ngan }\end{array}$ \\
\hline (1) & (2) & (3) & $\begin{array}{c}(4)=(5+6+7+8+9 \\
+10)\end{array}$ & (5) & (6) & (7) & (8) & (9) & (10) & (11) \\
\hline 1 & $\begin{array}{c}\text { Kargo } \\
\text { Bandara } \\
\text { Kualanamu }\end{array}$ & 2013 & $4,046,409$ & 25,259 & $2,603,098$ & $1,195,191$ & 11,857 & 46,522 & 164,483 & $\begin{array}{c}\text { Konsul } \\
\tan \\
\text { MK }\end{array}$ \\
\hline 2 & $\begin{array}{c}\text { Kargo } \\
\text { Bandara } \\
\text { BIJB }\end{array}$ & 2017 & $6,611,993$ & 46,633 & $3,851,000$ & $1,888,559$ & 47,306 & 294,152 & 484,343 & $\begin{array}{c}\text { Konsul } \\
\tan \\
\text { MK }\end{array}$ \\
\hline 3 & $\begin{array}{c}\text { Kargo } \\
\text { Bandara } \\
\text { NYIA }\end{array}$ & 2018 & $9,767,542$ & 44,957 & $7,006,650$ & $1,691,975$ & 35,492 & 123,881 & 864,587 & $\begin{array}{c}\text { Konsul } \\
\tan \\
\text { MK }\end{array}$ \\
\hline
\end{tabular}

Keterangan : $(*)$ = Dalam Jutaan Rupiah

Tabel 3 : Tabulasi Harga Pekerjaan pada Proyek Pembangunan Gedung Kargo Bandara Tahun 2013-2018 per $\mathbf{m}^{2}$, Setelah Perhitungan Time Value

\begin{tabular}{|l|c|c|c|c|c|c|c|c|c|}
\hline No & Nama Proyek & Tahun & Jumlah Biaya & $\begin{array}{c}\text { Pek } \\
\text { Persiapan } \\
(\mathbf{Y})^{*}\end{array}$ & $\begin{array}{c}\text { Pek } \\
\text { Struktur } \\
\left(\mathbf{X}_{\mathbf{2}} *\right.\end{array}$ & $\begin{array}{c}\text { Pek } \\
\text { Arsitektur } \\
\left(\mathbf{X}_{\mathbf{3}}\right)^{*}\end{array}$ & $\begin{array}{c}\text { Pek } \\
\text { Plumbing } \\
\left(\mathbf{X}_{\mathbf{4}}\right)^{*}\end{array}$ & $\begin{array}{c}\text { Pek } \\
\text { Mekanikal } \\
\left(\mathbf{X}_{\mathbf{5}}\right)^{*}\end{array}$ & $\begin{array}{c}\text { Pek } \\
\text { Elektrikal } \\
\left(\mathbf{X}_{\mathbf{6}}\right)^{*}\end{array}$ \\
\hline$(1)$ & $(2)$ & $(3)$ & $(4)=(5+6+7+8+9+10)$ & $(5)$ & $(6)$ & $(7)$ & $(8)$ & $(9)$ & $(10)$ \\
\hline 1 & $\begin{array}{c}\text { Kargo Bandara } \\
\text { Kualanamu }\end{array}$ & 2013 & 13.530 .213 & 84.459 & 8.704 .129 & 3.996 .429 & 39.647 & 155.559 & 549.990 \\
\hline 2 & $\begin{array}{c}\text { Kargo Bandara } \\
\text { BIJB }\end{array}$ & 2017 & 6.850 .686 & 48.316 & 3.990 .021 & 1.956 .736 & 49.014 & 304.771 & 501.828 \\
\hline 3 & $\begin{array}{c}\text { Kargo Bandara } \\
\text { NYIA }\end{array}$ & 2018 & 13.438 .898 & 44.957 & 8.933 .148 & 3.436 .833 & 35.492 & 123.881 & 864.587 \\
\hline
\end{tabular}

Dari data 3 proyek pembangunan gedung kargo bandara yang dianalisa, bisa diketahui rata-rata proporsi komponen biaya per $\mathrm{M}^{2}$ luas bangunannya. Proporsi komponen biaya diurutkan dari yang terbesar sampai yang terkecil yaitu : $\left(\mathrm{X}_{2}\right)$ pekerjaan struktur ratarata sebesar $63.93 \%,\left(\mathrm{X}_{3}\right)$ pekerjaan arsitektur rata-rata sebesar $27.77 \%,\left(\mathrm{X}_{6}\right)$ pekerjaan elektrikal rata-rata sebesar 5.67\%, $\left(\mathrm{X}_{5}\right)$ pekerjaan mekanikal rata-rata sebesar $1.73 \%$, $\left(\mathrm{X}_{1}\right)$ ) pekerjaan persiapan rata-rata sebesar $0.53 \%$ dan $\left(\mathrm{X}_{4}\right)$ pekerjaan plumbing rata-rata sebesar $0.37 \%$. 
Tabel 4 : Tabulasi Proporsi Komponen Biaya per $\mathrm{m}^{2}$ pada Proyek Pembangunan Kargo Bandara Tahun 2013-2018

\begin{tabular}{|c|c|c|c|c|c|c|c|c|c|}
\hline No & $\begin{array}{c}\text { Nama } \\
\text { Proyek }\end{array}$ & Tahun & $\begin{array}{c}\text { Jumlah Biaya } \\
(\mathbf{Y})^{*}\end{array}$ & $\begin{array}{c}\text { Pek } \\
\text { Persiapan } \\
\left(\mathbf{X}_{1}\right)^{*}\end{array}$ & $\begin{array}{c}\text { Pek } \\
\text { Struktur } \\
\\
\left(\mathrm{X}_{2}\right)^{*}\end{array}$ & $\begin{array}{c}\text { Pek } \\
\text { Arsitektur } \\
\\
\left(\mathbf{X}_{3}\right)^{*}\end{array}$ & $\begin{array}{c}\text { Pek } \\
\text { Plumbing } \\
\left(\mathbf{X}_{4}\right)^{*}\end{array}$ & $\begin{array}{c}\text { Pek } \\
\text { Mekanikal } \\
\left(\mathbf{X}_{5}\right)^{*}\end{array}$ & $\begin{array}{c}\text { Pek } \\
\text { Elektrik } \\
\text { al } \\
\left(\mathrm{X}_{6}\right)^{*}\end{array}$ \\
\hline (1) & (2) & (3) & $(4)=(5+6+7+8+9+10)$ & (5) & (6) & (7) & (8) & (9) & (10) \\
\hline 1 & $\begin{array}{c}\text { Kargo } \\
\text { Bandara } \\
\text { Kualanamu }\end{array}$ & 2013 & $13,119,569$ & 81,896 & $8,439,957$ & $3,875,137$ & 38,444 & 150,838 & 533,298 \\
\hline 2 & $\begin{array}{l}\text { Kargo } \\
\text { Bandara } \\
\text { BIJB }\end{array}$ & 2017 & $6,850,686$ & 48,316 & $3,990,021$ & $1,956,736$ & 49,014 & 304,771 & 501,828 \\
\hline 3 & $\begin{array}{c}\text { Kargo } \\
\text { Bandara } \\
\text { NYIA }\end{array}$ & 2018 & $13,438,898$ & 44,957 & $8,933,148$ & $3,436,833$ & 35,492 & 123,881 & 864,587 \\
\hline & Prosentase & & $100 \%$ & $0.53 \%$ & $63.93 \%$ & $27.77 \%$ & $0.37 \%$ & $1.73 \%$ & $5.67 \%$ \\
\hline
\end{tabular}

Total biaya (Y) sebagai variabel terikat dan

$\left(\mathrm{x}_{2}\right)$ Pek Struktur, $\left(\mathrm{x}_{3}\right)$ Pek Arsitektur dan $\left(\mathrm{x}_{6}\right)$

Pek Elektrikal sebagai variabel bebas.
Kemudian variabel-variabel tersebut disusun sebagai input data untuk dianalisis.

Tabel 5 : Perbandingan Komponen Biaya

\begin{tabular}{|c|c|c|c|c|c|c|}
\hline No & Nama Proyek & Tahun & $\begin{array}{c}\text { Jumlah Biaya } \\
(\mathbf{Y})^{*}\end{array}$ & $\begin{array}{c}\text { Pek Struktur } \\
\left(\mathbf{X}_{\mathbf{2}}\right)^{*}\end{array}$ & $\begin{array}{c}\text { Pek Arsitektur } \\
\left(\mathbf{X}_{\mathbf{3}}\right)^{*}\end{array}$ & $\begin{array}{c}\text { Pek Elektrikal } \\
\left(\mathbf{X}_{\mathbf{6}}\right)^{*}\end{array}$ \\
\hline$(1)$ & $(2)$ & $(3)$ & $(4)=(6+7+10)$ & $(6)$ & $(7)$ & $(10)$ \\
\hline 1 & $\begin{array}{c}\text { Kargo Bandara } \\
\text { Kualanamu }\end{array}$ & $\mathbf{2 0 1 3}$ & $\mathbf{1 3 , 1 1 9 , 5 6 9}$ & $\mathbf{8 , 4 3 9 , 9 5 7}$ & $\mathbf{3 , 8 7 5 , 1 3 7}$ & $\mathbf{5 3 3 , 2 9 8}$ \\
\hline 2 & $\begin{array}{c}\text { Kargo Bandara } \\
\text { BIJB }\end{array}$ & $\mathbf{2 0 1 7}$ & $\mathbf{6 , 8 5 0 , 6 8 6}$ & $\mathbf{3 , 9 9 0 , 0 2 1}$ & $\mathbf{1 , 9 5 6 , 7 3 6}$ & $\mathbf{5 0 1 , 8 2 8}$ \\
\hline 3 & $\begin{array}{c}\text { Kargo Bandara } \\
\text { NYIA }\end{array}$ & $\mathbf{2 0 1 8}$ & $\mathbf{1 3 , 4 3 8 , 8 9 8}$ & $\mathbf{8 , 9 3 3 , 1 4 8}$ & $\mathbf{3 , 4 3 6 , 8 3 3}$ & $\mathbf{8 6 4 , 5 8 7}$ \\
\hline 4 & $\begin{array}{c}\text { Apartemen Acacia } \\
\text { Nartemen Zamzam } \\
\text { Tower }\end{array}$ & 2015 & $6,398.72$ & $1,455.75$ & $2,817.01$ & 864.65 \\
\hline 6 & $\begin{array}{c}\text { Apartemen } \\
\text { Gardenia }\end{array}$ & 2015 & $6,407.65$ & $1,464.44$ & $2,872.57$ & 847.32 \\
\hline
\end{tabular}

Keterangan : $\left(^{*}\right)=$ Poin no 4, 5, 6 merupakan data tambahan yang bertujuan untuk membantu proses perhitungan data penelitian

\section{Uji Normalitas}


Pengujian dilakukan uji normalitas

Kolmogorov Smirnov, yaitu dengan maksud untuk mengetahui apakah sebaran distribusi datanya normal atau tidak.

Syarat :

$p>0,01$ (Normal) atau tidak terdapat perbedaan data yg signifikan $p<0,01$ (Tidak Normal) atau terdapat perbedaan data yg signifikan

Hasil Pengujian :

1. Variabel Terikat (Y)

2. Variabel Bebas $\left(\mathrm{x}_{2}, \mathrm{x}_{3}\right.$ dan $\left.\mathrm{x}_{6}\right)$

Tabel 6 : Hasil Uji Normalitas

One-Sample Kolmogorov-Smirnov Test

\begin{tabular}{|c|c|c|c|c|c|}
\hline & & $Y$ & $\times 2$ & $\times 3$ & $\times 6$ \\
\hline$N$ & & 6 & 6 & 6 & 6 \\
\hline \multirow[t]{2}{*}{ Normal Parameters ${ }^{a, b}$} & Mean & 5571408,87 & 3562510,62 & 1545648,00 & 316795,90 \\
\hline & Std. Deviation & 6533230,674 & 4261582,434 & 1806829,577 & 369213,047 \\
\hline \multirow[t]{3}{*}{ Most Extreme Differences } & Absolute &, 303 &, 298 &, 304 &, 304 \\
\hline & Positive &, 303 & .298 & .304 &, 304 \\
\hline & Negative &,- 209 &,- 207 &,- 196 &,- 196 \\
\hline
\end{tabular}

a. Test distribution is Normal.

Berdasarkan output program SPSS

menghasilkan :

Variabel Y menghasilkan $p=0,090$ dan untuk variabel X menghasilkan $p=0,103,0,089$ dan 0,087

Tabel 7 : Hasil Uji Korelasi

\begin{tabular}{|c|c|c|c|c|c|}
\hline \multicolumn{6}{|c|}{ Correlations } \\
\hline & & $\mathrm{Y}$ & $\times 2$ & $\times 3$ & $\times 6$ \\
\hline \multirow[t]{3}{*}{$\checkmark$} & Pearson Correlation & 1 & $.999^{x \approx}$ & $.996^{x \approx}$ & $.950^{x *}$ \\
\hline & Sig. (2-tailed) & &, 000 & .000 & .004 \\
\hline & $N$ & 6 & 6 & 6 & 6 \\
\hline \multirow[t]{3}{*}{$\times 2$} & Pearson Correlation & $.999^{x \pi}$ & 1 & $.992^{x \pi}$ & $.948^{\pi \times}$ \\
\hline & Sig. (2-tailed) & .000 & & .000 & .004 \\
\hline & $N$ & 6 & 6 & 6 & 6 \\
\hline \multirow[t]{3}{*}{$\times 3$} & Pearson Correlation & $.996^{\star x}$ & $.992^{n \pi}$ & 1 & $.924^{n \times}$ \\
\hline & Sig. (2-tailed) & .000 & .000 & & .008 \\
\hline & $\mathrm{N}$ & 6 & 6 & 6 & 6 \\
\hline \multirow[t]{3}{*}{$\times 6$} & Pearson Correlation & $.950^{x \approx}$ & $.948^{n \pi}$ & $.924^{\pi x}$ & 1 \\
\hline & Sig. (2-tailed) & .004 &, 004 & .008 & \\
\hline & $\mathrm{N}$ & 6 & 6 & 6 & 6 \\
\hline
\end{tabular}

Hipotesis penelitian ini adalah :

$\mathrm{H}_{0-1} \quad: \mathrm{r}=0 ; \mathrm{X}_{1}$ tidak ada hubungan antara pekerjaan struktur dengan nilai total pekerjaan

$\mathrm{H}_{1-1} \quad: \mathrm{r}=0 ; \mathrm{X}_{1}$ ada hubungan antara pekerjaan struktur dengan nilai total pekerjaan

$\mathrm{H}_{0-2} \quad: \mathrm{r}=0 ; \mathrm{X}_{1}$ tidak ada hubungan antara pekerjaan arsitektur dengan nilai total pekerjaan

$\mathrm{H}_{1-2} \quad: \mathrm{r}=0 ; \mathrm{X}_{1}$ ada hubungan antara pekerjaan arsitektur dengan nilai total pekerjaan

$\mathrm{H}_{0-3} \quad: \mathrm{r}=0 ; \mathrm{X}_{1}$ tidak ada hubungan antara pekerjaan elektrikal dengan nilai total pekerjaan

$\mathrm{H}_{1-3} \quad: \mathrm{r}=0 ; \mathrm{X}_{1}$ ada hubungan antara pekerjaan elektrikal dengan nilai total pekerjaan 
Tabel 8 : Koefisien

\begin{tabular}{|c|c|c|c|c|c|c|}
\hline \multicolumn{7}{|c|}{ Coefficients $^{a}$} \\
\hline & & \multicolumn{2}{|c|}{ Unstandardized Coefficients } & \multirow{2}{*}{$\begin{array}{c}\text { Standardized } \\
\text { Coefficients } \\
\text { Beta }\end{array}$} & \multirow[b]{2}{*}{$\mathrm{t}$} & \multirow[b]{2}{*}{ Sig. } \\
\hline & & $\mathrm{B}$ & Std. Error & & & \\
\hline \multirow[t]{4}{*}{1} & (Constant) & 208,453 & 48,985 & & 4,255 &, 051 \\
\hline & $\times 2$ &, 747 &, 000 & 487 & 8378,116 &, 000 \\
\hline & $\times 3$ & 1,505 &, 000 & ,416 & 8574,973 &, 000 \\
\hline & $x_{6}$ & 1,844 &, 000 & 104 & 5302,683 &, 000 \\
\hline
\end{tabular}

a. Dependent Variable: $Y$

Dari Tabel Koefisien menunjukkan bahwa nilai signifikansi $<0,01$ pada komponen biaya pekerjaan struktur $\left(\mathrm{X}_{2}\right)$, biaya pekerjaan arsitektur $\left(\mathrm{X}_{3}\right)$ dan pekerjaan elektrikal $\left(\mathrm{X}_{6}\right)$ mempengaruhi biaya total proyek (Y) pada tingkat kepercayaan 99\%.

- $\quad$ Nilai $\beta$ constant adalah 208,453 yang artinya jika pekerjaan struktur, pekerjaan arsitektur, dan pekerjaan elektrikal diabaikan, maka nilai total pekerjaan adalah sebesar Rp 208,453.

- $\quad$ Nilai $\beta\left(\mathrm{X}_{2}\right)$ menunjukkan nilai total pekerjaan struktur akan meningkat Rp $0,747 /$ per $m^{2}$, jika terjadi tambahan biaya pada pekerjaan tersebut sebesar Rp 1000,-.

- $\quad$ Nilai $\beta\left(\mathrm{X}_{3}\right)$ menunjukkan nilai total pekerjaan arsitektur akan meningkat Rp 1,505/per $m^{2}$, jika terjadi tambahan biaya pada pekerjaan tersebut sebesar Rp $1000,-$.
- $\quad$ Nilai $\beta\left(\mathrm{X}_{6}\right)$ menunjukkan nilai total pekerjaan elektrikal akan meningkat Rp 1,844/per $m^{2}$, jika terjadi tambahan biaya pada pekerjaan tersebut sebesar Rp $1000,-$.

\section{Pengujian Model}

Proses perhitungan biaya estimasi dalam penelitian ini dengan cara memasukkan harga pekerjaan struktur, pekerjaan arsitektur, dan pekerjaan elektrikal ke dalam persamaan regresi. Adapun hasil estimasi biaya dengan Cost Significant Model didapat dari cara membagi biaya estimasi model dengan Cost Model Factor (CMF). CMF merupakan ratarata rasio dari biaya estimasi model dengan biaya aktual. Berdasarkan hasil perhitungan didapat rata-rata $\mathrm{CMF}$ sebesar $=1,0007$. Berikut tabel rangkuman hasil perhitungan Cost Model Factor (CMF). 
Tabel 7 Hasil Perhitungan Cost Model Factor (CMF)

\begin{tabular}{|c|c|c|c|c|c|c|c|}
\hline No & $\begin{array}{c}\text { Nama } \\
\text { Proyek }\end{array}$ & $\begin{array}{c}\text { Total } \\
\text { Biaya Riil } \\
\text { Proyek/M } \\
\text { (Y) }\end{array}$ & $\begin{array}{c}\text { Pek } \\
\text { Struktur/M2 } \\
\left(\mathbf{X}_{2}\right)\end{array}$ & $\begin{array}{c}\text { Pek } \\
\text { Arsitektur/M2 } \\
\left(\mathbf{X}_{3}\right)\end{array}$ & $\begin{array}{c}\text { Pek } \\
\text { Elektrikal//M2 } \\
\left(\mathrm{X}_{6}\right)\end{array}$ & $\begin{array}{c}\text { Biaya Estimasi "Cost Significant } \\
\text { Model"/ } / \mathbf{M}^{2}\left(\mathbf{Y}^{\prime}\right)\end{array}$ & $\begin{array}{l}\text { Cost } \\
\text { Model } \\
\text { Factor } \\
(\mathrm{CMF})\end{array}$ \\
\hline (1) & (2) & (3) & (4) & (5) & (6) & $\begin{array}{c}(7)= \\
208,453+0,746(4)+1,505(5)+1,844(6)\end{array}$ & $(8)=(7) /(3)$ \\
\hline 1 & $\begin{array}{c}\text { Kargo } \\
\text { Bandara } \\
\text { Kualanamu } \\
\end{array}$ & 13.530 .213 & 8.704 .129 & 3.996 .429 & 549.990 & 13.120 .339 & 0,9697 \\
\hline 2 & $\begin{array}{l}\text { Kargo } \\
\text { Bandara } \\
\text { BIJB }\end{array}$ & 6.850 .686 & 3.990 .021 & 1.956 .736 & 501.828 & 6.851 .013 & 1,0000 \\
\hline 3 & $\begin{array}{c}\text { Kargo } \\
\text { Bandara } \\
\text { NYIA } \\
\end{array}$ & 13.438 .898 & 8.933 .148 & 3.436 .833 & 864.587 & 13.440 .002 & 1,0001 \\
\hline 4 & $\begin{array}{l}\text { Apartemen } \\
\text { Acacia }\end{array}$ & $6.398,72$ & $1.455,75$ & $2.817,01$ & 864,65 & 6.393 & 0,9992 \\
\hline 5 & $\begin{array}{l}\text { Apartemen } \\
\text { Zamzam } \\
\text { Tower }\end{array}$ & 6493,83 & $1.498,71$ & $2.853,02$ & 872,18 & 6.492 & 0,9997 \\
\hline 6 & $\begin{array}{l}\text { Apartemen } \\
\text { Gardenia }\end{array}$ & $6.407,65$ & $1.464,44$ & $2.872,57$ & 847,32 & 6.442 & 1,0054 \\
\hline & & & & & & Rata - rata $=$ & 0.9957 \\
\hline
\end{tabular}

Tabel 8 Komparasi Model Estimasi Pekerjaan Pembangunan Kargo Bandara

\begin{tabular}{|c|c|c|c|c|c|c|}
\hline & \multirow[b]{2}{*}{ Nama Proyek } & \multirow{2}{*}{$\begin{array}{c}\text { Biaya Riil } \\
\text { Proyek (dalam } \\
\text { ribuan) }\end{array}$} & \multicolumn{4}{|c|}{ Cost Significant Model } \\
\hline & & & $\begin{array}{l}\text { Jml Pek } \\
\text { (dalam } \\
\text { ribuan) }\end{array}$ & $\begin{array}{l}\text { Luas } \\
\text { Bang. }\end{array}$ & $\begin{array}{c}\text { Biaya Total } \\
\text { (dalam ribuan) }\end{array}$ & Akurasi \\
\hline (1) & (2) & (3) & (4) & (5) & $(6)=(4) \times(5)$ & $(7)=((6)-(3)) /(3)$ \\
\hline 1 & $\begin{array}{c}\text { Kargo Bandara } \\
\text { Kualanamu }\end{array}$ & 18.526.282.106 & 13.530 .213 & $4.578,5$ & 61.947 .404 .001 & $234 \%$ \\
\hline 2 & $\begin{array}{c}\text { Kargo Bandara } \\
\text { BIJB }\end{array}$ & 29.621 .728 .214 & 6.851 .013 & 4.480 & 30.692 .536 .681 & $3,61 \%$ \\
\hline 3 & $\begin{array}{c}\text { Kargo Bandara } \\
\text { NYIA }\end{array}$ & 56.261 .042 .866 & 13.440 .002 & 5.760 & 77.414 .412 .108 & $37,6 \%$ \\
\hline 4 & $\begin{array}{c}\text { Apartemen } \\
\text { Acacia }\end{array}$ & $318.140 .206,38$ & $6.393,38$ & $51.385,00$ & $328.523 .622,16$ & $3,3 \%$ \\
\hline 5 & $\begin{array}{c}\text { Apartemen } \\
\text { Zamzam Tower }\end{array}$ & $2.499 .995 .121,48$ & $6.491,56$ & $39.787,00$ & $258.279 .586,90$ & $3,31 \%$ \\
\hline 6 & $\begin{array}{c}\text { Apartemen } \\
\text { Gardenia }\end{array}$ & $514.458 .618,47$ & $6.441,97$ & $82.978,00$ & $534.542 .032,27$ & $3,9 \%$ \\
\hline & & & & & & $47.68 \%$ \\
\hline
\end{tabular}

Keterangan: (*) Poin 4, 5,6 merupakan data tambahan yang bertujuan untuk membantu proses perhitungan data penelitian.

Analisis biaya estimasi pada penelitian ini diperoleh dari perhitungan biaya aktual (biaya pelaksanaan) suatu proyek yang diamati. Kemudian, perhitungan untuk tingkat akurasi adalah dengan cara menghitung selisih dari estimasi cost significant model dengan biaya pelaksanaan, lalu dibagi dengan biaya pelaksanaan, dan dikali $100 \%$. 


\section{KESIMPULAN}

Berdasarkan hasil penelitian yang telah dilaksanakan oleh penulis dapat disimpulkan bahwa sebagai berikut.

1) Berdasarkan perhitungan dengan metode cost significant model, maka komponen item pekerjaan yang memiliki pengaruh secara signifikan terhadap biaya keseluruhan pembangunan kargo bandara adalah sebagai berikut.

$\mathrm{X}_{2}$ Pekerjaan Struktur $\quad: 63,93 \%$

$\mathrm{X}_{3}$ Pekerjaan Arsitektur $: 27,77 \%$

$\mathrm{X}_{6}$ Pekerjaan Elektrikal $\quad: 5,69 \%$

2) Pembangunan kargo bandara di tiga propinsi, yakni Propinsi Jawa Barat (di Majalengka), Propinsi Jawa Tengah (di Kulon Progo), dan Propinsi Sumatra Utara (di Medan) memiliki model estimasi biaya melalui penggunaan metode cost significant model adalah sebagai berikut.

$\mathbf{Y}=208,453+0,747 \mathbf{X}_{\mathbf{2}}+1,505 \mathbf{X}_{\mathbf{3}}+$

\section{$1,844 \mathbf{X}_{6}$}

Keterangan:

$\mathrm{Y}=$ Nilai Total Biaya Pekerjaan

$\mathrm{X}_{2}=$ Pekerjaan Struktur

$\mathrm{X}_{3}=$ Pekerjaan Arsitektur

$\mathrm{X}_{6}=$ Pekerjaan Elektrikal

3) Dilihat dari persentase keakuratan hasil estimasi biaya pembangunan kargo bandara di 3 provinsi dengan menggunakan metode Cost Significant Model diperoleh rata-rata $47,68 \%$, serta menurut Standar AACE International menunjukkan model ini berada di class
Klasifikasi AACE International yang memiliki batas bawah $-5 \%$ sampai $-15 \%$ dan batas atas $+5 \%$ sampai $+20 \%$ dan cocok untuk perkiraan penawaran sesuai tabel 2.2 pada halaman 25. Kemudian, perkiraan biaya dengan menggunakan Cost Significant Model menghasilkan estimasi yang lebih teliti sebagai dasar awal pembangunan kargo bandara.

\section{DAFTAR PUSTAKA}

[1] M. Andhini S., "Respon Masyarakat Terhadap Rencana Pembangunan Bandara Internasional Jawa Barat (BIJB) di Kecamatan Kertajati Kabupaten Majalengka. Hlm. 1," Universitas Pendidikan Indonesia, Bandung, 2013.

[2] K. P. R. Indonesia, "Bandar Udara Internasional Kertajati," Kemenhub RI, Jakarta, 2015.

[3] D. P. Sinurat, "Perencaan Gedung Terminal Barang Bandara Internasional Jawa Barat. Hlm. 11," Bandung, 2008.

[4] I. D. G. Agung Pemayun, "Praktek Estimasi Biaya dengan Metode Cost Significant Model pada Bangunan Gedung yang Memakai Arsitektural Bali. Hlm. 3," Universitas Atma Jaya, Yogyakarta, 2003.

[5] N. L. Sariani, "Estimasi Biaya Konstruksi Gedung dengan Metode Cost Significant Model (Studi Kasus Proyek Konstruksi Gedung Pemerintah di Kabupaten Jembrana)," Universitas Udayana, Denpasar, 2011. 